\section{5. 女子体探遗手の足庶に阙する研究}

東京女子体育大学○伊藤 純子，清川 誠一 女子のスポーツに拈いて、いわゆる「足痛」は日常し ばしば経験する所である。

私達は「足痛」の原因には，思春期の体重急增による 足底筋，腱，靶带，関節包群の扁平足様变化が惹起され るものと考え，体操部員 43 名を対象として，非荷重足 と片側荷重足穹害のレ線計测を行い，横含氏の足窎基 標準值と比較し，考察を加えた。

要約すると

1. 非荷重足において，陸上部員群では，距眼関節が 下降の傾向を示しているが，体操部員群では，横倉 氏の基潐値より上昇している。

2. 片㑡荷重足において，体操部員群，陸上部員群去 に下降の傾向が見られるが，特に，陸上部員群では

\section{6. 月释の同查について（第 1 赤）}

和歌山大学教育学部 $\bigcirc$ 刍井 恭子, 南 佐三

城亘方法和歌山県下小学览童, 和歌山市内 10 栈， 魚村地方 6 校，豊村地方 6 校，僻地校6校(これについ ては後記で述べるが調查した児童に执いて来潮者○であ つたので調查人数より除いた）計児童数 2455 名, 調查 期間は，昭和 42 年 4 月より 9 月上旬迄とし，初潮の平 均年令, 都市，農村，漁村の年令比較，月経日数，身体 的变化，月経時に拁いての体育時の参加，月経の知識に ついて報告する。.

调查结果和歌山県下における初潮年令は11.63才 で和歌山県下小学校児童の初潮年令は都市 11.65 寸，農 村 11.73 才，漁村 11.67 才と者市，漁村，農村の順とな り，来潮者の\%は，都市 $22.38 \%$ ，農村 $13.63 \%$ ，漁村 $17.46 \%$ と都市が费村に比べ約 $9 \%$ の差がある。これを 初経者年令別にすると，都市9才で 0.1\%，10才 $19 \%$ ， 11 才 $47.6 \% ， 12$ 才 $32.4 \%$ ，農村 9 才 $1.6 \% ， 10$ 才 10 $\%, 11$ 才 $35.8 \%, 12$ 才 $52.5 \%$ ，湧村 9 才 $1 \% ， 10$ 才 $16.8 \% ， 11$ 才 $54.7 \% ， 12$ 才 $27.3 \%$ となり11才代で漁 戒地方の児童が都市の $47.6 \%$ 上り上回るのは和歌山県 の地理的条件（唃村地方の潮岬と農村地方の応其とでは
距腿関節，距踵関節は著しく下降を示し，距踵関節 は扁平様変化を示した。

すなわち陸上競技部員群では足底節, 腱, 靶帯, 関節包 群の強さを越える運動負荷の反復により，足窎㦈が低下 し，その過渡期において足痛を訴方るが，㻞平足粎変化 の完成と共に消旔する運動適応と考えられた.

また，体操部員群において見られた非荷重足穹龨の上

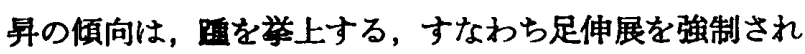
る運動負荷により, 足底筋, 腱, 靶带, 関節包群の強さ の変化および解剖学的位置異常を招来せしめ，足痛を港 起するのではないかと考えられます。

今後更に，女子スポーツと「足痛」に関して対照群の 增加と足蹠面積，筋電図など多方面にわたり検討を加 え，その成因を解明し，女子スポーツ指導上の参考にし たい.

年間平均搨 $\mathrm{C} 2$ 2 3度の美異がある) とよるものと思わ れる.次に表の如く，来潮者における月経日数及び身体 的随伴症状，及び来潮者の体育時の参加状態, 月䅅の知 識については, 初経後の周期が不定である昌童が多数で あることが上げられ月経中の随伴症状においては，腹痛 を訴学る児童が $54.4 \%$ と半数強であることが特筆され 小学校児童来潮者の月経時と腹痛との関係は課題であ る. 前述したが和歌山県下僻地に批いて調查した小学児 童について来潮者○であるといら調査結果が表れたのは 今後の貫重な资料になるとおすわれる.

月経に関する諸調查表（\%)

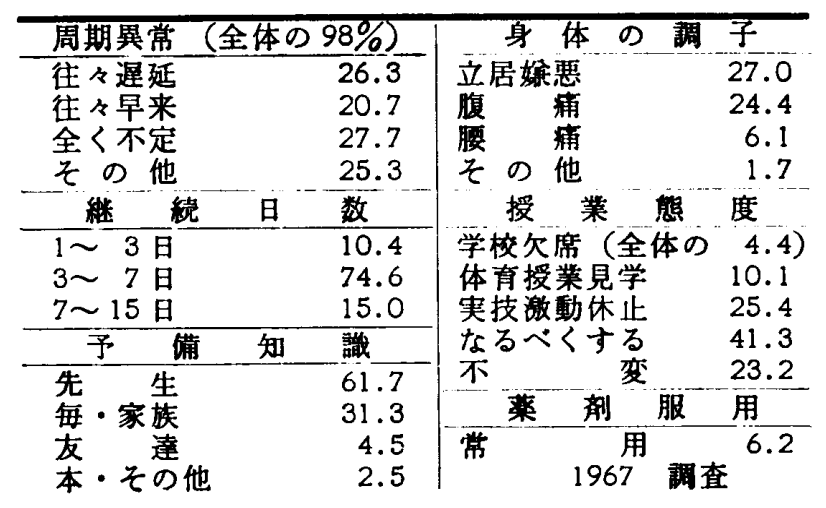

